\title{
11. CARBON CARBONATE RESULTS
}

\author{
Deep Sea Drilling Project, East Coast Repository \\ Lamont-Doherty Geological Observatory, Palisades, N. Y.
}

\section{METHOD}

Samples of 2 cubic centimeters in size were dried and ground in a mortar to homogeneity. Approximately 0.05 gram samples were then run on the LECO carbon analyzer to find the per cent total carbon in each sample. A duplicate set of samples weighing about 0.15 gram was treated with hydrocholoric acid, washed with distilled water, and then dried before running on the carbon analyzer. The result obtained was the amount of organic carbon in the sample. Using the formula: per cent total carbon minus per cent organic carbon multiplied by 8.33 , the per cent calcium carbonate in the sample was calculated.

\section{RESULTS}

\section{Calcium Carbonate}

Estimates of the calcium carbonate per cent were made from smear slide preparations on board ship. In most places these visual estimates were moderately accurate. Where errors occurred, they were due to overestimating the amount of carbonate present. At Site 1 in particular, the visual estimates were usually double the amount of carbonate actually revealed by analysis. At other sites, the errors were lower and probably due to a variety of contributory factors: smear slides were not always taken at the same locations as the carbon carbonate samples; the method of actually preparing the smear slide introduces errors; and, finally, the human error which is based on the difficulty of estimating the percentage weight of components in a slide by visual means.

Complete carbon and calcium carbonate analyses are given as Table 1, and a scatter diagram to illustrate the distribution of carbonate within the sediments is given as Figure 1.

\section{Site 1}

The piston core from Site 1 contains 20 per cent carbonate in clay in its upper part, and 10 to 15 per cent in clay, silty clay and silt in its lower part. The higher value in the upper part is due to the post-Pleistocene coccolith content.

Drill Cores $1,2,3$, and 5 contain 15 to 20 per cent carbonate in quartzose, silty clay and clayey, quartz silt.
Further down in Hole 1, the carbonate increases slightly to over 20 per cent in Cores 6 through 9-the sediment here is silty clay. Two lower values of 4 and 11 per cent occur in Core 9, yet the sediment shows no visual differences. The carbonate content of all these cores is probably attributable to terrigenous grains derived from glacial flour.

\section{Site 2}

All of the sediments cored in Hole 2 have a moderately high carbonate content varying from 35 to 50 per cent. The sediments here are calcilutites containing abundant foraminifera in the upper part and calcareous nannoplankton lower down.

\section{Site 3}

Drilling at Site 3 indicates a variety of sediments whose carbonate content varies from 1 to 50 per cent.

Cores 1 through 4 contain quartzose, silty clays with quartz turbidites having intermediate carbonate values of 11 to 24 per cent. From Core 5 down to 8 , the carbonate content increases to the 35 to 50 per cent level in coccolith oozes and calcareous turbidites.

At Core 9 there is a marked decrease in carbonate content to below 10 per cent. The sediment in this core is a montmorillonitic clay. Cores 10 and 11 are also low in carbonate containing 16 to 18 per cent in a quartzose silty clay with some volcanogenic constituents.

\section{Site 4}

Drilling at Site 4 reveals a complex sedimentary history, and, owing to the variety of sediments present, the carbonate values vary from 0 to over 80 per cent.

Core 1 contains 50 per cent carbonate in a calcarenitic turbidite, but no carbonate in clay formed entirely of clay minerals. Core 2 is a calcarenitic turbidite with 45 per cent carbonate. Core 3 contains only 20 per cent carbonate in a clay consisting mainly of clay minerals but with some calcareous fossils. Core 4 has a high carbonate content of 65 per cent as it is a coccolith chalk ooze.

The highest carbonate values of 77 to over 80 per cent were from calcarenitic turbidites in Core 1 of Hole 4A. 


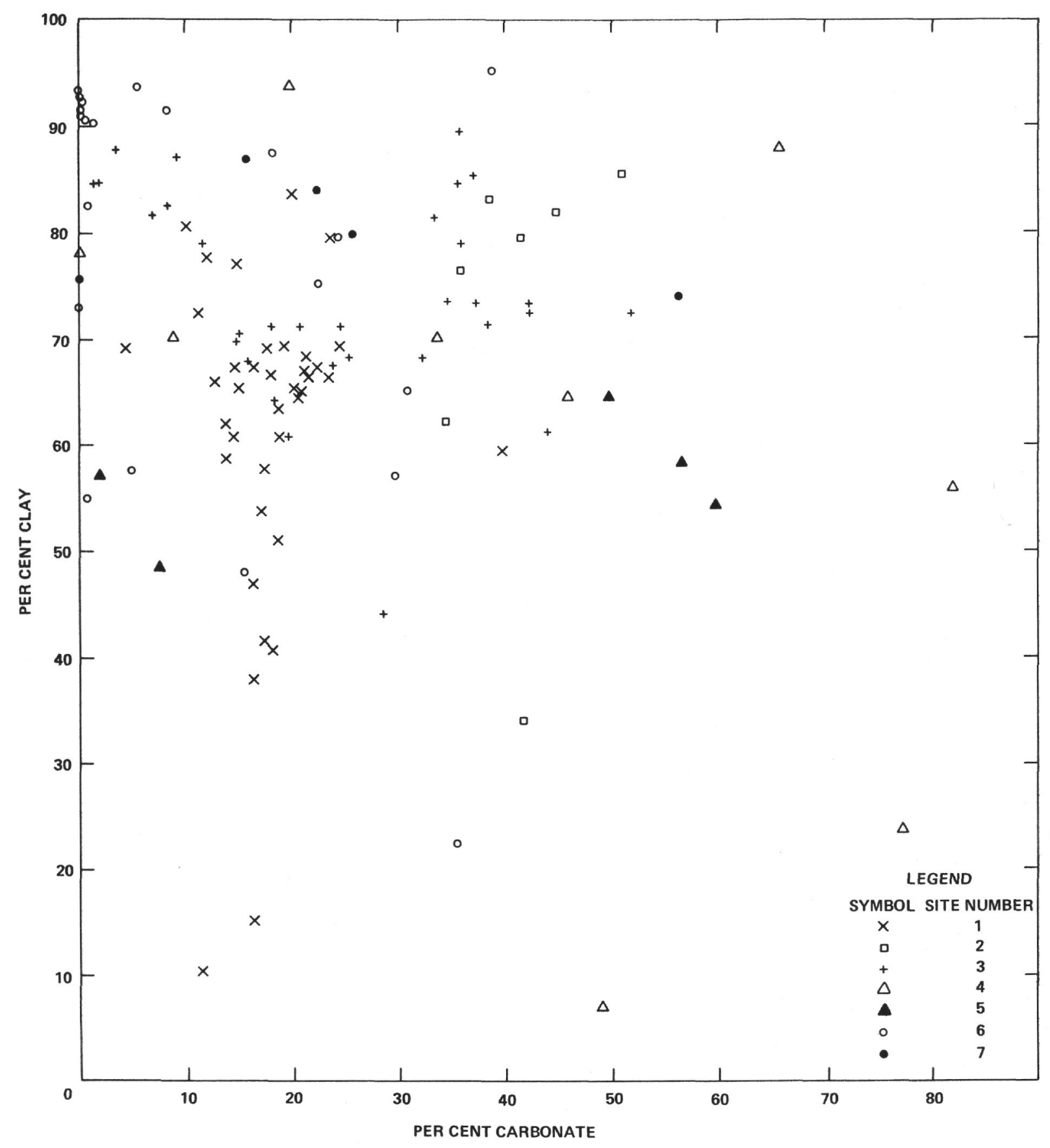

Figure 1. Relationship between clay content and carbonate content for Leg 1 samples. 
Site 5

The carbonate content at Site 5 also shows considerable variation according to sediment type.

The top of Core 1 contains only 7 per cent carbonate in a silty clay consisting mainly of clay minerals and quartz. Moving down in Core 1, the sediment changes to a coccolith ooze containing 49 to 59 per cent carbonate. Core 2 contains 56 per cent carbonate in a coccolith-rich marl. In Core 3, the carbonate decreases to less than 1 per cent in a silty clay consisting mainly of chlorite.

\section{Site 6}

Sediments from Site 6 are generally low in carbonate with a few values in the medium range. These fluctuations in carbonate content indicate the variety of sediments deposited at this site.

Cores 1 and 2 contain nonfossiliferous deep-sea brown clays comprising mostly clay minerals and practically no carbonate. One value of 18 per cent carbonate was revealed in the analysis, but the sediment shows no obvious difference here.

In Core 3, diatom-coccolith clays contain about 23 per cent carbonate. Lower down, the carbonate content is less than 1 per cent in a silty clay of predominantly siliceous composition. In Core 4 , the carbonate varies from 15 to 30 per cent in sediments of mixed pelagic and turbidite origin consisting of clay minerals, detrital carbonate, and siliceous fossils. A diatom ooze in the upper part of Core 5 contains no carbonate. Lower down, carbonate increases to 38 per cent in a diatomcoccolith clay. Core 6 contains 35 per cent carbonate in sand-silt-clay of turbidite origin and only 4 per cent in a silty clay of "laminite facies."

\section{Site 7}

Sediments from Holes 7 and 7A show a wide range in carbonate content. Brown to tan clays in Core 1 of Hole 7 contain 22 to 56 per cent carbonate depending upon the abundance of coccoliths. The coccoliths occur in irregular patches of clay and are probably of turbidite origin. They have now been stirred into the brown clay either by burrowing organisms or by the actual drilling of the core.

Values of 25.8 and 22.5 per cent carbonate in Cores 2 and 3 of Hole 7A seem anomalously high for deep-sea, brown clay. These relatively high carbonate values are due possibly to the presence of microgranules of rhodochrosite (manganese carbonate). If this is so, then the carbonate percentage should be calculated as manganese carbonate, not calcium carbonate, thus giving values of 29.7 and 25.8 per cent, respectively.

\section{Carbon}

With the exception of Site 4, all of the samples contain less than 1 per cent organic carbon, and the total carbon varies from less than 1 per cent to 7 per cent. Site 4 has a much higher content of total carbon and organic carbon.

\section{Site 1}

Sediments from Site 1 average 2.7 per cent total carbon, and 0.6 per cent organic carbon giving a ratio of $4.5: 1$.

\section{Site 2}

At Site 2, the sediments contain an average of 5.1 per cent total carbon, but only 0.2 per cent organic carbon, giving a ratio of $25: 1$. Obviously, nearly all of the carbon is in the form of a nonorganic material, i.e., carbonate carbon.

\section{Site 3}

Site 3 sediments have an intermediate total carbon organic carbon ratio of $12: 1$. The total carbon averages 3.5 per cent and the organic carbon 0.3 per cent.

\section{Site 4}

This site shows a great range of both carbon values. Total carbon varies from 0.1 to 11.8 per cent and organic carbon from 0.1 to 5.0 per cent. The value of 5 per cent organic carbon from 4-1-1-39-40 has the effect of reducing the carbonate value to 49.0 per cent, compared with values of 70 to 80 per cent carbonate from Hole 4A, which has a similar high total carbon value, but only about 2 per cent organic carbon. The core descriptions for Site 4 show all of these high total carbon sediments to be calcarenitic turbidites with possibly one important difference: the sediment with high organic carbon from Core 1 contains abundant clay minerals, but those from Hole 4A, Core 1 do not contain significant amounts of clay minerals. It would appear that possibly the organic carbon forms some affinity for the clay minerals.

\section{Site 5}

Total carbon in sediments from Site 5 ranges from 0.2 to 7.4 per cent of which an average of 0.2 per cent is organic carbon.

\section{Site 6}

Cores 1 and 2 from Hole 6 and Core 1 from Hole 6A have an average of 0.5 per cent total carbon of which 0.1 per cent is organic carbon. Cores 3 through 6 average 2.7 per cent total carbon, but only 0.2 per cent organic carbon. It can be seen, therefore, that the ratio of total carbon to organic carbon increases from $5: 1$ in the upper part of this site, to $13: 1$ lower down.

Site 7

Site 7 shows a range of 0.1 to 6.8 per cent total carbon and 0.1 to 0.9 per cent organic carbon. 
TABLE 1

Leg 1 Carbon Carbonate Results

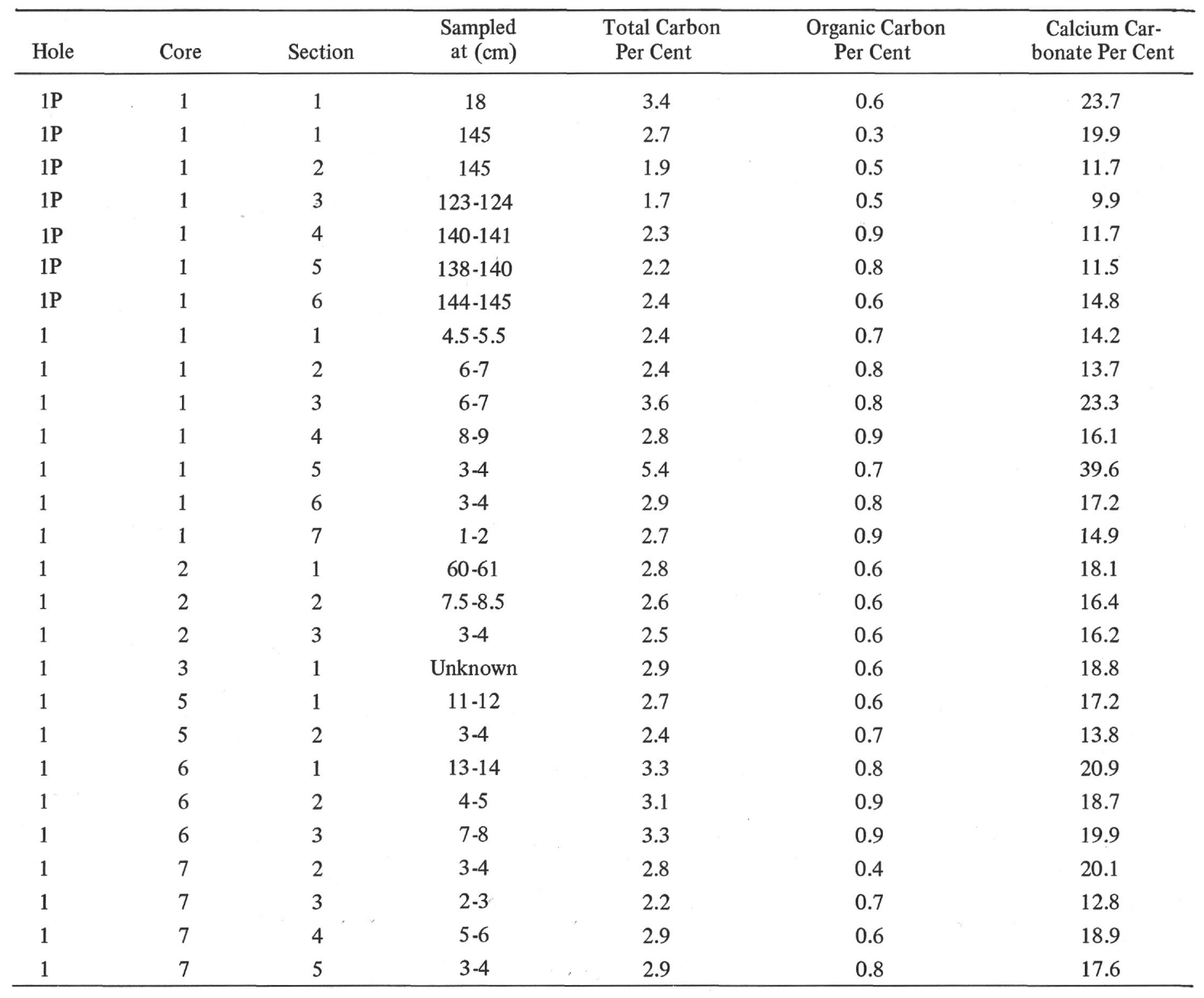


TABLE 1 - Continued

\begin{tabular}{ccccccc}
\hline Hole & Core & Section & $\begin{array}{c}\text { Sampled } \\
\text { at }(\mathrm{cm})\end{array}$ & $\begin{array}{c}\text { Total Carbon } \\
\text { Per Cent }\end{array}$ & $\begin{array}{c}\text { Organic Carbon } \\
\text { Per Cent }\end{array}$ & $\begin{array}{c}\text { Calcium Car- } \\
\text { bonate Per Cent }\end{array}$ \\
\hline 1 & 7 & 6 & $5-6$ & 3.2 & 0.5 & 22.5 \\
1 & 7 & 7 & $7-8$ & 2.9 & 0.7 & 18.2 \\
1 & 8 & 2 & $19-20$ & 3.2 & 0.6 & 21.3 \\
1 & 8 & 3 & $5-6$ & 2.4 & 0.5 & 16.2 \\
1 & 8 & 4 & $5-6$ & 2.2 & 0.4 & 14.8 \\
1 & 8 & 5 & $4-5$ & 2.8 & 0.2 & 21.4 \\
1 & 8 & 6 & $4-5$ & 2.6 & 0.1 & 21.1 \\
1 & 8 & 7 & $4-5$ & 2.8 & 0.2 & 21.5 \\
1 & 9 & 3 & 5 & 1.3 & 0.8 & 4.3 \\
1 & 9 & 4 & $9-10$ & 3.7 & 0.7 & 24.6 \\
1 & 9 & 5 & $4-5$ & 2.8 & 0.5 & 24.2 \\
1 & 9 & 5 & $79-80$ & 3.5 & 0.6 & 11.2 \\
1 & 9 & 6 & $5-6$ & 1.9 & 0.5 & 17.1 \\
1 & 9 & 7 & $6-7$ & 2.6 & 0.6 & 35.7 \\
2 & 1 & 2 & $4-5$ & 4.5 & 0.2 & 41.4 \\
2 & 1 & 3 & $7-8$ & 5.2 & 0.2 & 41.6 \\
2 & 2 & 1 & $39-40$ & 5.3 & 0.3 & 48.5 \\
2 & 3 & 1 & $105-106$ & 4.8 & 0.2 & 34.2 \\
2 & 3 & 2 & $9-10$ & 5.7 & 0.3 & 51.0 \\
2 & 3 & 3 & $9-10$ & 4.3 & 0.2 & 20.8 \\
2 & 4 & 2 & $6-7$ & 6.2 & 0.1 & 11.7 \\
3 & 1 & 1 & $6-7$ & 3.2 & 0.7 & 14.8 \\
3 & 1 & 2 & $9-10$ & 2.3 & 0.8 & 15.0 \\
3 & 2 & 1 & $51-52$ & 3.6 & 0.7 & \\
3 & 2 & 2 & $39-40$ & 2.5 & 0.7 & 0.7 \\
3 & 2 & 3 & $8-9$ & 2.5 & & \\
\hline & & & & & & \\
\hline
\end{tabular}


TABLE 1 - Continued

\begin{tabular}{|c|c|c|c|c|c|c|}
\hline Hole & Core & Section & $\begin{array}{l}\text { Sampled } \\
\text { at }(\mathrm{cm})\end{array}$ & $\begin{array}{l}\text { Total Carbon } \\
\text { Per Cent }\end{array}$ & $\begin{array}{l}\text { Organic Carbon } \\
\text { Per Cent }\end{array}$ & $\begin{array}{l}\text { Calcium Car- } \\
\text { bonate Per Cent }\end{array}$ \\
\hline 3 & 3 & 2 & $6-7$ & 2.6 & 0.3 & 19.1 \\
\hline 3 & 4 & 1 & $41-42$ & 3.2 & 0.4 & 23.8 \\
\hline 3 & 5 & 1 & $42-43$ & 4.3 & 0.2 & 34.6 \\
\hline 3 & 5 & 2 & 15 & 4.1 & 0.2 & 32.3 \\
\hline 3 & 5 & 3 & $9-10$ & 5.4 & 0.3 & 42.2 \\
\hline 3 & 5 & 4 & $5-6$ & 4.5 & 0.2 & 35.9 \\
\hline 3 & 5 & 5 & $40-41$ & 5.6 & 0.3 & 43.9 \\
\hline 3 & 6 & 1 & $46-47$ & 6.4 & 0.2 & 51.8 \\
\hline 3 & 6 & 2 & $4-5$ & 5.7 & 0.3 & 44.6 \\
\hline 3 & 7 & 1 & $29-30$ & 4.7 & 0.2 & 37.2 \\
\hline 3 & 7 & 2 & $3-4$ & 4.1 & 0.2 & 33.1 \\
\hline 3 & 7 & 3 & $5-6$ & 3.2 & 0.2 & 25.2 \\
\hline 3 & 7 & 4 & $7-8$ & 5.0 & 0.2 & 39.8 \\
\hline 3 & 8 & 1 & $99-100$ & 4.5 & 0.2 & 35.5 \\
\hline 3 & 8 & 2 & $9-10$ & 4.6 & 0.3 & 35.8 \\
\hline 3 & 8 & 3 & $9-10$ & 3.6 & 0.2 & 28.6 \\
\hline 3 & 8 & 4 & $13-14$ & 4.7 & 0.1 & 38.4 \\
\hline 3 & 8 & 5 & $10-11$ & 4.6 & 0.1 & 37.0 \\
\hline 3 & 8 & 6 & $12-13$ & 5.4 & 0.3 & 42.1 \\
\hline 3 & 9 & 2 & $15-17$ & 0.6 & 0.2 & 1.7 \\
\hline 3 & 9 & 3 & 9-10 & 1.4 & 0.3 & 9.2 \\
\hline 3 & 9 & 4 & $6-7$ & 0.5 & 0.3 & 1.6 \\
\hline 3 & 9 & 5 & $6-7$ & 1.1 & 0.3 & 6.9 \\
\hline 3 & 9 & 6 & $9-10$ & 1.3 & 0.9 & 3.3 \\
\hline 3 & 9 & 7 & $8-9$ & 1.4 & 0.4 & 8.2 \\
\hline 3 & 10 & 2 & $6-7$ & 2.4 & 0.2 & 18.3 \\
\hline 3 & 11 & 1 & 60 & 2.3 & 0.3 & 16.1 \\
\hline
\end{tabular}


TABLE 1 - Continued

\begin{tabular}{|c|c|c|c|c|c|c|}
\hline Hole & Core & Section & $\begin{array}{l}\text { Sampled } \\
\text { at }(\mathrm{cm})\end{array}$ & $\begin{array}{l}\text { Total Carbon } \\
\text { Per Cent }\end{array}$ & $\begin{array}{l}\text { Organic Carbon } \\
\text { Per Cent }\end{array}$ & $\begin{array}{l}\text { Calcium Car- } \\
\text { bonate Per Cent }\end{array}$ \\
\hline 4 & 1 & 1 & $39-40$ & 10.9 & 5.0 & 49.1 \\
\hline 4 & 1 & 2 & $59-60$ & 0.9 & 0.1 & 6.7 \\
\hline 4 & 1 & 3 & $6-7$ & 4.0 & 0.1 & 33.6 \\
\hline 4 & 1 & 4 & $6-7$ & 1.1 & 0.1 & 8.9 \\
\hline 4 & 1 & 5 & $20-21$ & 1.2 & 0.1 & 9.7 \\
\hline 4 & 1 & 6 & $10-11$ & 0.1 & 0.1 & 0.0 \\
\hline 4 & 2 & 1 & $10-11$ & 6.2 & 0.7 & 45.9 \\
\hline 4 & 3 & 1 & $24-25$ & 2.7 & 0.3 & 19.8 \\
\hline 4 & 4 & 1 & $17-18$ & 9.7 & 1.8 & 65.8 \\
\hline $4 \mathrm{~A}$ & 1 & 1 & $5-6$ & 9.5 & 2.2 & 77.1 \\
\hline $4 \mathrm{~A}$ & 1 & 2 & 111 & 11.8 & 1.9 & 81.9 \\
\hline $4 \mathrm{~A}$ & 1 & 3 & $10-11$ & 9.9 & 0.1 & 78.2 \\
\hline 5 & 1 & 1 & $9-10$ & 1.0 & 0.1 & 7.3 \\
\hline 5 & 1 & 2 & $90-91$ & 6.1 & 0.1 & 49.7 \\
\hline 5 & 1 & 3 & $3-4$ & 7.4 & 0.3 & 59.6 \\
\hline 5 & 2 & 1 & $88-89$ & 7.4 & 0.7 & 55.8 \\
\hline 5 & 3 & 1 & $52-53$ & 0.3 & 0.1 & 1.9 \\
\hline 6 & 1 & 1 & $10-11$ & 0.1 & 0.1 & 0.0 \\
\hline 6 & 1 & 2 & $10-11$ & 0.1 & 0.1 & 0.0 \\
\hline 6 & 1 & 3 & $7-8$ & 0.1 & 0.1 & 0.3 \\
\hline 6 & 1 & 4 & $5-6$ & 0.5 & 0.1 & 3.3 \\
\hline 6 & 2 & 1 & $15-16$ & 0.1 & 0.1 & 0.5 \\
\hline 6 & 2 & 2 & $6-7$ & 2.7 & 0.6 & 18.1 \\
\hline 6 & 2 & 3 & $7-8$ & 0.2 & 0.1 & 1.1 \\
\hline 6 & 2 & 4 & $10-11$ & 0.2 & 0.2 & \\
\hline 6 & 2 & 5 & $20-21$ & 0.1 & 0.1 & \\
\hline
\end{tabular}


TABLE 1 - Continued

\begin{tabular}{|c|c|c|c|c|c|c|}
\hline Hole & Core & Section & $\begin{array}{l}\text { Sampled } \\
\text { at }(\mathrm{cm})\end{array}$ & $\begin{array}{l}\text { Total Carbon } \\
\text { Per Cent }\end{array}$ & $\begin{array}{l}\text { Organic Carbon } \\
\text { Per Cent }\end{array}$ & $\begin{array}{c}\text { Calcium Car- } \\
\text { bonate Per Cent }\end{array}$ \\
\hline 6 & 2 & 6 & $10-11$ & 1.1 & 0.1 & 8.2 \\
\hline 6 & 3 & 2 & $10-11$ & 2.8 & 0.1 & 22.6 \\
\hline 6 & 3 & 3 & $44-50$ & 3.7 & 0.2 & 29.1 \\
\hline 6 & 3 & 4 & $11-12$ & 0.2 & 0.1 & 0.8 \\
\hline 6 & 4 & 1 & $9-11$ & 2.2 & 0.3 & 15.6 \\
\hline 6 & 4 & 2 & $15-16$ & 3.8 & 0.3 & 29.8 \\
\hline 6 & 4 & 3 & $8-9$ & 3.8 & 0.2 & 30.8 \\
\hline 6 & 5 & 1 & $10-11$ & 0.2 & 0.2 & 0.0 \\
\hline 6 & 5 & 2 & $80-81$ & 5.0 & 0.4 & 38.7 \\
\hline 6 & 6 & 1 & $7-8$ & 4.4 & 0.1 & 35.6 \\
\hline 6 & 6 & 2 & $4-5$ & 0.7 & 0.1 & 4.9 \\
\hline $6 \mathrm{~A}$ & 1 & 1 & $19-20$ & 0.2 & 0.1 & 0.8 \\
\hline $6 \mathrm{~A}$ & 1 & 2 & $10-11$ & 0.6 & 0.1 & 4.2 \\
\hline $6 \mathrm{~A}$ & 1 & 4 & $20-21$ & 0.4 & 0.1 & 2.5 \\
\hline $6 \mathrm{~A}$ & 1 & 6 & $10-11$ & 0.8 & 0.1 & 5.8 \\
\hline 7 & 1 & 1 & $21-22$ & 6.8 & 0.1 & 56.4 \\
\hline 7 & 1 & 2 & $21-22$ & 2.9 & 0.2 & 22.4 \\
\hline 7 & 1 & 6 & $7-8$ & 0.3 & 0.1 & 1.7 \\
\hline $7 \mathrm{~A}$ & 2 & 1 & $22-23$ & 3.2 & 0.1 & 25.8 \\
\hline $7 \mathrm{~A}$ & 3 & 1 & $18-19$ & 2.8 & 0.1 & 22.5 \\
\hline $7 \mathrm{~A}$ & 3 & 2 & $5-6$ & 0.1 & 0.1 & \\
\hline
\end{tabular}

